\title{
Front Matter: 9386
}

, "Front Matter: 9386," Proc. SPIE 9386, Practical Holography XXIX: Materials and Applications, 938618 (28 April 2015); doi: 10.1117/12.2197664

SPIE. Event: SPIE OPTO, 2015, San Francisco, California, United States 


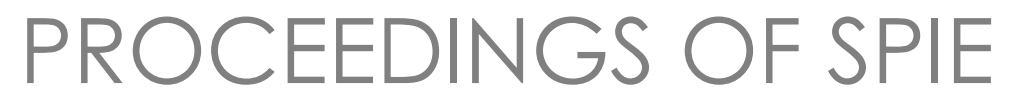

\title{
Practical Holography XXIX: Materials and Applications
}

\author{
Hans I. Bjelkhagen \\ V. Michael Bove Jr. \\ Editors
}

8 and 11 February 2015

San Francisco, California, United States

Sponsored and Published by

SPIE

Volume 9386 
The papers included in this volume were part of the technical conference cited on the cover and title page. Papers were selected and subject to review by the editors and conference program committee. Some conference presentations may not be available for publication. The papers published in these proceedings reflect the work and thoughts of the authors and are published herein as submitted. The publisher is not responsible for the validity of the information or for any outcomes resulting from reliance thereon.

Please use the following format to cite material from this book:

Author(s), "Title of Paper," in Practical Holography XXIX: Materials and Applications, edited by Hans I. Bjelkhagen, V. Michael Bove Jr., Proceedings of SPIE Vol. 9386 (SPIE, Bellingham, WA, 2015) Article CID Number.

ISSN: 0277-786X

ISBN: 9781628414769

\section{Published by}

\section{SPIE}

P.O. Box 10, Bellingham, Washington 98227-0010 USA

Telephone +1 3606763290 (Pacific Time) · Fax +1 3606471445

SPIE.org

Copyright @ 2015, Society of Photo-Optical Instrumentation Engineers.

Copying of material in this book for internal or personal use, or for the internal or personal use of specific clients, beyond the fair use provisions granted by the U.S. Copyright Law is authorized by SPIE subject to payment of copying fees. The Transactional Reporting Service base fee for this volume is $\$ 18.00$ per article (or portion thereof), which should be paid directly to the Copyright Clearance Center (CCC), 222 Rosewood Drive, Danvers, MA 01923. Payment may also be made electronically through CCC Online at copyright.com. Other copying for republication, resale, advertising or promotion, or any form of systematic or multiple reproduction of any material in this book is prohibited except with permission in writing from the publisher. The CCC fee code is 0277-786X/15/\$18.00.

Printed in the United States of America.

Publication of record for individual papers is online in the SPIE Digital Library.

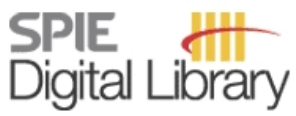

SPIEDigitallibrary.org

Paper Numbering: Proceedings of SPIE follow an e-First publication model, with papers published first online and then in print. Papers are published as they are submitted and meet publication criteria. A unique citation identifier (CID) number is assigned to each article at the time of the first publication. Utilization of CIDs allows articles to be fully citable as soon as they are published online, and connects the same identifier to all online, print, and electronic versions of the publication. SPIE uses a six-digit CID article numbering system in which:

- The first four digits correspond to the SPIE volume number.

- The last two digits indicate publication order within the volume using a Base 36 numbering

system employing both numerals and letters. These two-number sets start with 00, 01, 02, 03, 04, $05,06,07,08,09,0 A, 0 B \ldots$. OZ, followed by 10-1Z, 20-2Z, etc.

The CID Number appears on each page of the manuscript. The complete citation is used on the first page, and an abbreviated version on subsequent pages. 


\title{
Contents
}

\author{
vii Authors \\ ix Conference Committee
}

\section{SESSION 1 MATERIALS AND PROCESSES}

938601 Edge-lit volume holograms recorded by free space exposure: diffraction by $2^{\text {nd }}$ harmonics in Bayfol HX film [9386-1]

938602 Beam propagation ratios measurement based on transmissive liquid crystal spatial light modulator [9386-2]

938604 Hyperspectral digital holography of microobjects [9386-4]

\section{SESSION 2 DIGITAL HOLOGRAPHY I}

938605 Generalized experimental phase extraction algorithm for speckle interferometry [9386-5]

938606 Differentiation method for phase recovery [9386-6]

938607 Diffraction pattern of gratings with erosion [9386-7]

\section{SESSION 3 DIGITAL HOLOGRAPHY II}

938609 Distortion-free broadband holograms: a novel class of elements utilizing the wavelength-independent geometric phase [9386-10]

$93860 \mathrm{~A}$ Computation of Fresnel holograms and diffraction-specific coherent panoramagrams for full-color holographic displays based on anisotropic leaky-mode modulators [9386-11]

9386 OB Improved real-time holographic video display using super-fast-refresh liquid crystal films [9386-12]

\section{SESSION 4 HOLOGRAPHY, ART, AND PERCEPTION}

9386 OC Time within time: 3D printed sculptures within holographic art practice [9386-13]

9386 OD Seeing yourself seeing [9386-14]

9386 OE Archiving Saudi heritage using the holographic medium [9386-15] 
9386 OG Holographic data storage at 2+ Tbit/in² [9386-17]

$9386 \mathrm{OH} \quad$ Compensation of laser wavelength drift in collinear holographic storage system [9386-18]

$9386 \mathrm{Ol} \quad$ Automated determination of volume phase hologram parameters [9386-19]

9386 OK Design of wide angle holographic waveguide monocular head-mounted display using photopolymer [9386-21]

\section{POSTER SESSION}

$9386 \mathrm{OL}$ Optimization of the switch-back technique used for fast occlusion-processing in computer holography [9386-22]

9386 OM Holographic gratings with NOA65 adhesive and edible colorant [9386-23]

9386 ON Optimization of design-wavelength for unobtrusive chromatic aberration in high-definition color computer holography [9386-24]

$938600 \quad$ Holographic gratings in dichromated gelatin with edible dyes [9386-25]

9386 OP Reduction of phase volume error in off-axis quantitative phase microscopy using optimum phase-shift [9386-26]

$93860 Q \quad$ Stability of holographic gratings recorded on photopolymer films using acrylamide as monomer and $N, N^{\prime}$-methylenebisacrylamide [9386-27]

9386 OR Increasing reconstruction quality of diffractive optical elements displayed with LC SLM [9386-28]

9386 OS UV recording with vinyl acetate and muicle dye films [9386-29]

9386 OT Improved hidden surface removal method for computer-generated alcove hologram [9386-30]

9386 OU Security enhanced optical one-time password authentication method by using digital holography [9386-31]

9386 OV Hologram-like interactive three-dimensional display using LED array type persistence of vision [9386-32]

9386 OW Non-destructive testing of an original XVI century painting on wood by ESPI system [9386-33]

9386 OX Recovering data from noisy fringe patterns from a portable digital speckle pattern interferometer for in-situ inspection of a painting hanging on the wall [9386-34] 
9386 OY Experiment on three-dimensional display using spatial cross modulation method [9386-35]

$93860 Z$ Interferometric study on Gouy phase anomaly of microlens array [9386-36]

Proc. of SPIE Vol. $9386938618-5$

Downloaded From: https://www.spiedigitallibrary.org/conference-proceedings-of-spie on 26 Apr 2023 Terms of Use: https://www.spiedigitallibrary.org/terms-of-use 
Proc. of SPIE Vol. 9386 938618-6

Downloaded From: https://www.spiedigitallibrary.org/conference-proceedings-of-spie on 26 Apr 2023 Terms of Use: https://www.spiedigitallibrary.org/terms-of-use 


\section{Authors}

Numbers in the index correspond to the last two digits of the six-digit citation identifier (CID) article numbering system used in Proceedings of SPIE. The first four digits reflect the volume number. Base 36 numbering is employed for the last two digits and indicates the order of articles within the volume. Numbers start with 00, 01, 02, 03, 04, 05, 06, 07, 08, 09, 0A, 0B...0Z, followed by 10-1Z, 20-2Z, etc.

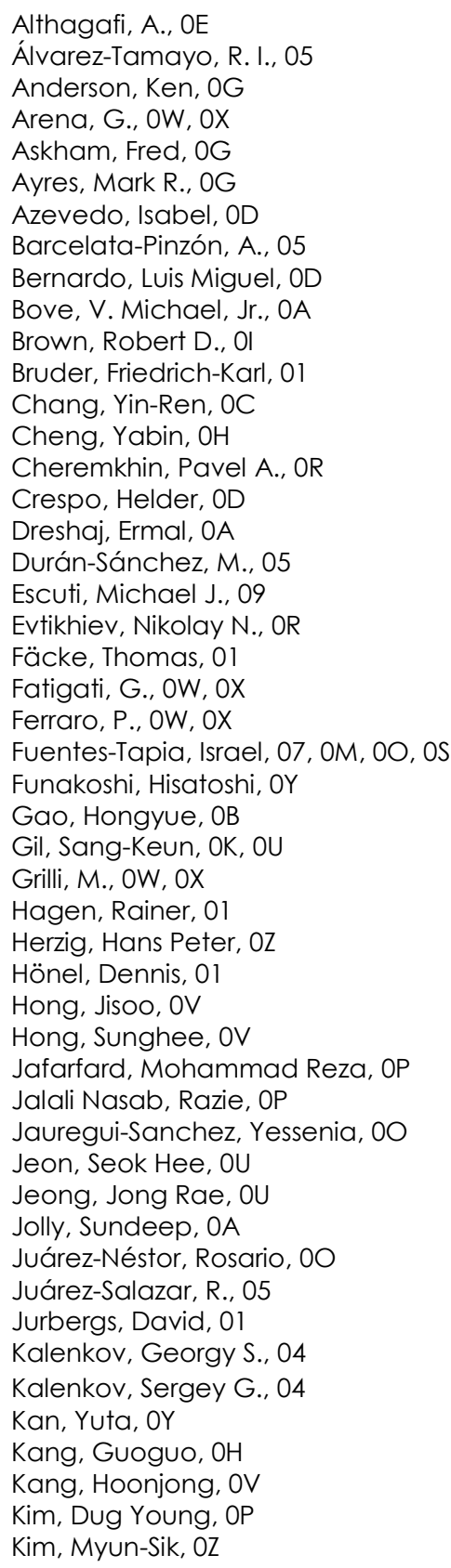

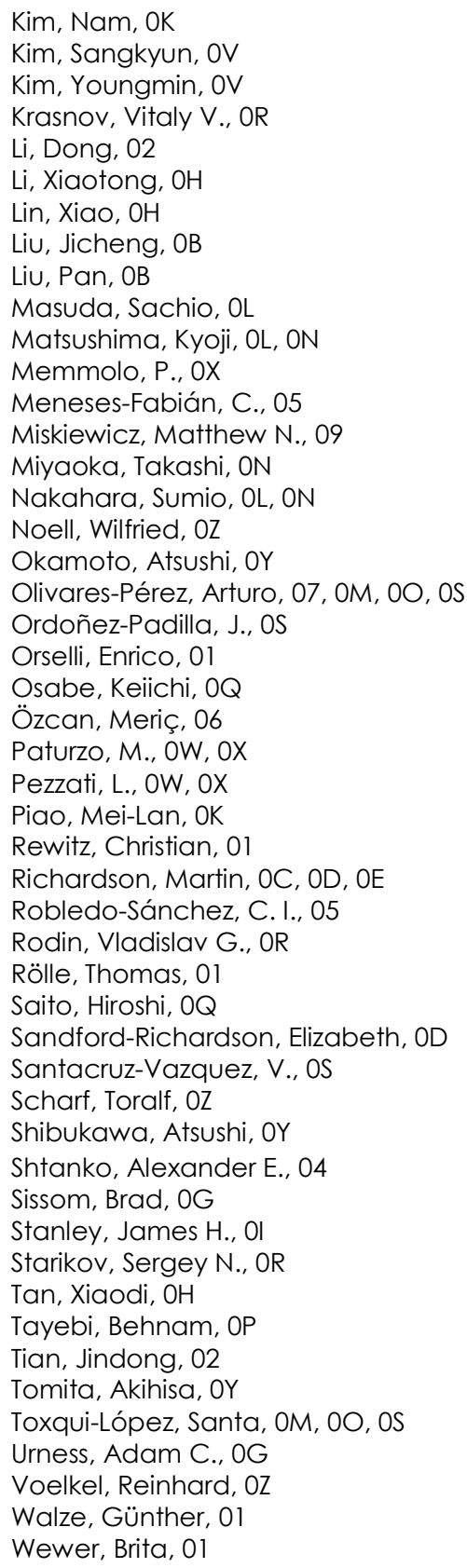


Xiang, Xiao, 09

Yamaguchi, Takeshi, OT

Yao, Qiuxiang, OB

Yoshikawa, Hiroshi, OT

Yu, Yingjie, OB

Zeng, Chao, OB

Zhang, Lei, 02

Zheng, Huadong, OB

Zheng, Zhenxiang, OB

Proc. of SPIE Vol. $9386938618-8$

Downloaded From: https://www.spiedigitallibrary.org/conference-proceedings-of-spie on 26 Apr 2023 Terms of Use: https://www.spiedigitallibrary.org/terms-of-use 


\section{Conference Committee}

Symposium Chairs

David L. Andrews, University of East Anglia (United Kingdom)

Alexei L. Glebov, OptiGrate Corporation (United States)

Symposium Co-chairs

Jean-Emmanuel Broquin, IMEP-LAHC (France)

Shibin Jiang, AdValue Photonics, Inc. (United States)

Program Track Chair

Liang-Chy Chien, Kent State University (United States)

Conference Chairs

Hans I. Bjelkhagen, Glyndwr University (United Kingdom) and Hansholo Consulting Ltd. (United Kingdom)

V. Michael Bove Jr., MIT Media Laboratory (United States)

Conference Program Committee

Frank C. Fan, Shenzhen AFC Technology Co., Ltd. (China)

Gerald L. Heidt, Wasatch Photonics, Inc. (United States)

Toshio Honda, Toppan Printing Co., Ltd. (Japan)

Fujio Iwata, Toppan Printing Co., Ltd. (Japan)

Tung H. Jeong, Lake Forest College (United States)

Michael A. Klug, Zebra Imaging, Inc. (United States)

Alkiviadis Lembessis, The Hellenic Institute of Holography (Greece)

Martina L. Mrongovius, RMIT University (Australia) and Center for the Holographic Arts (United States) and Academy of Media Arts, Cologne KHM (Germany)

Martin J. Richardson, De Montfort University (United Kingdom)

Hiroshi Yoshikawa, Nihon University (Japan) 
Proc. of SPIE Vol. $9386938618-10$

Downloaded From: https://www.spiedigitallibrary.org/conference-proceedings-of-spie on 26 Apr 2023 Terms of Use: https://www.spiedigitallibrary.org/terms-of-use 